\title{
RESIDUAL RISKS OF PAYMENT PROVISIONS IN FIDIC AND JCT CONDITIONS: A QUANTITY SURVEYOR'S VIEW
}

\author{
${ }^{* 1}$ Sanni, A. G., ${ }^{2}$ Adebiyi, O. J. and ${ }^{3}$ Okorie, N. V.
}

\author{
*IDepartment of Quantity Surveying, University of Benin (UNIBEN), Benin City, Nigeria. \\ Phone: 07038179270 Email: agsanni@gmail.com \\ ${ }^{2}$ Department of Quantity Surveying, University of Benin (UNIBEN), Benin City, Nigeria. \\ Phone: 08037337901 Email: adebiyiola@gmail.com \\ ${ }^{3}$ Department of Quantity Surveying, University of Benin (UNIBEN), Benin City, Nigeria. \\ Phone: 07064899835 Email:v.okorie@yahoo.com
}

\begin{abstract}
The obligee and obligor of all cost-related commitments in construction contracts are governed by the conditions of contract. Like in all human engagements, risk is inevitable in construction contracts. This exploratory overview examined residual risks associated with payment provisions in Federation Internationale Des Ingenieurs-Consiels (FIDIC) and Joint Contracts Tribunal (JCT) conditions of contract in Nigerian construction industry. The selected payment provisions were advance payment, interim valuation, retention and final payment. The methodology comprises: (i) critical examination of payment provisions, (ii) scenario building of problem situations, (iii) assessing the sensitivity of the provisions to contractual conflict, and (iv) evaluating the effect on construction cost administration. Disbursement and amortization of Advance payment in FIDIC are more secured than JCT. Interim valuation in FIDIC allows the contractor to make claims for delayed issuance of interim certificate but FIDIC does not give the contractor such right because all application for payments must be made by the contractor to the engineer. It would take a contractor in FIDIC-based contract a longer time for maturity of final payment than in JCT-based contract. It is recommended that a contractor in FIDIC-based contract should get retention bond in lieu of deduction of retention money to enhance its liquidity.
\end{abstract}

Keywords: conflicts, contractors, construction contracts, FIDI, JCT, payments, quantitative survey

LICENSE: This work by Open Journals Nigeria is licensed and published under the Creative Commons Attribution License 4.0 International License, which permits unrestricted use, distribution, and reproduction in any medium, provided this article is duly cited.

COPYRIGHT: The Author(s) completely retain the copyright of this published article.

OPEN ACCESS: The Author(s) approves that this article remains permanently online in the open access (OA) mode.

QA: This Article is published in line with "COPE (Committee on Publication Ethics) and PIE (Publication Integrity \& Ethics)". 


\section{INTRODUCTION}

Construction contract is a legally enforceable agreement between the contracting parties on a project. Different parties are involved in the contract administration of construction project. These parties usually comprise the employer, and contractor, in addition to the project manager, project consultant(s), subcontractor(s) and suppliers. For effective construction cost, time and quality delivery, there must be a good working synergy among the contracting parties in a highly regulated approach to ensure the contractual processes and procedures are adhered to (Project Management Institute, 2008). In this regard, construction contract needs to be project-customized, mutually agreed, and contract obligations formalized by contracting parties. The standard of general conditions of contract (usually referred to as 'contract') in construction is being updated to meet modern construction contract administration challenges by several organizations. Conditions are drafted to define all the obligations of the parties to the contract and provide guidelines for resolving contingencies as the contract progresses. It is a body of readymade terms and conditions guiding the obligations in the contract (Kwakye, 1997). There are various types of contracts and conditions in the construction industry. The choice of contract type depends on the client or its representative, project procurement technique, and the existing considerations such as methodologies for managing risks, rigidity of price, discharge duration, responsibility for performance, complexity, and cost certainty. Some of the standard conditions are: Fédération Internationale des Ingénieurs-Conseils (FIDIC), Institution of Civil Engineers (ICE), New Engineering Contract (NEC), American Institute of Architects (AIA), Association of Chartered Architects (ACA), and Joint Contracts Tribunal (JCT) amongst others. These conditions contain suites to make it more suitable for contracts based on the project peculiarities.

These conditions have varying level of use in Nigeria construction industry. The most commonly used conditions in Nigeria are FIDIC and JCT and the choice are largely influenced by the project consultants that usually represent the client on major decisions (Sanni, 2012). FIDIC and JCT contracts are standard forms of contract that are part of standard families for procuring works or more recently consultancy services, works or services. The FIDIC recognizes the Engineer and JCT recognize the Architect/Contract Administrator as the Third-Party Certifier to the contract. The most commonly used FIDIC suite for contract administration is the conditions of contracts for Works of Civil engineering construction, Fourth Edition (1987 Red Book), which is still regarded by many employers and contractors as the preferred starting point for any new construction contract (Hillig, 1999). Since 1931, the JCT has produced standard form of construction contracts, guidance notes and other standard forms of documentation for use by the construction industry (International Bar Association, IBA; nd). According to Keeble (2009), the JCT suite consists of contract families made up of main contracts and subcontracts, together with their documents that can be used across certain contract families. JCT contract conditions are basically intended for domestic projects rather than international projects. Consequently, where it is used in international projects there is need for reasonable measure of amendments to make it suitable for the project and enhance its delivery benchmarks. Due to friction of interests and contingent occurrences, conflicts are inevitable in construction contracts. Some of these conflicts are 'errors' of omission or commission by the party in a contract in the discharge of its obligations. As the contract progresses, the conflicts may become worse if the contractual terms were not clear enough. For instance, if contracting parties do not have a clear understanding of what they have agreed upon, any claim may be considered as a fertile ground for contractual disputes (Murdoch and Hughes, 2008). Fenn et al. (2006) reported that some disputes were caused by misunderstanding and/or misinterpretation of contract, Lee (1994) showed that unfair contract clauses, vague definition of contract 
documents in terms of performance period, payment, variations expose contracts to conflicts, Jones (1994) highlighted inadequate contract drafting as a conflict trigger in construction contract, and Lo (2002) revealed that differences in contract interpretation between project parties would lead to construction conflict.

According to Sanni and Adebiyi (2017), the Nigeria construction industry is not immune to the industry challenges reported by Egan (1998). Construction projects in Nigeria are highly exposed to risks and disputes despite modifications of the conditions used to suit the project peculiarities (Sanni, 2012). Researches on construction contracts are extensive. However, research investigating effect of contract condition type on construction contracts cost administration is scarce. Therefore, the focus of this study is to assess the residual risks that construction contract executed using FIDIC or JCT conditions are disposed to. The specific aim of the exploration research is to assess the sensitivity of payment-related provisions in FIDIC and JCT to risk with a view to enhancing contract administration of construction projects in Nigeria. The study is limited to FIDIC and JCT because they are the most commonly used contracts in Nigeria and limited to payment provisions due to the professional training of the authors. The academic and professional training of the authors spanning over ten years provided expert judgement commonly associated with construction contract cost administration in Nigeria.

\section{LITERATURE REVIEW}

\section{RESIDUAL RISK}

Residual risk is the left-over threat that a system is exposed after mitigating considerations have been taken. It is a type of risk that is very difficult to be completely foreclosed in the organization of a system (Sanni, 2012). Residual risk in the context conditions of contracts is the latent risks that certain provisions in the conditions of contract are exposed to. Contracts are structured safety nets to protect the interest of all the parties and enhance the deliverables. However, there are contingent events that were not envisaged that would occur as the project progresses. "Risk! Construction projects have an abundance of it, contractors cope with it and owners pay for it'" (Flangan and Norman, 1993). This statement attests to the prevalence and implication of risk in construction project. In general, risk is unintended event that has the potential to divert certain objectives of a planned system from threshold targets if it occurs. In the context of the construction industry, it could be the likelihood of the occurrence of a definite event/factor or combination of events/factors which occur during the whole process of construction to the detriment of the project.

Risk analysis is done in order to make outcomes predictable. Construction industry is prone to more risk and uncertainty because getting a project from conception to completion involves managing a vast number of people with different skills and materials within varying procurement requirements (Flanagan and Stevens, 1995). It requires keeping within manageable limits every human and non-human resources with different strength and liabilities in related and non-related activities in order to attain the project goals. In construction projects, each of the three primary targets of cost, time and quality is likely to be subjected to risk and uncertainty. A realistic estimate is one which makes appropriate allowances for all those risks and uncertainties which can be anticipated from experience and foresight (Seeley, 1996). Risk managers should undertake or propose actions which eliminate the risks before they occur, or reduce the risks effects or uncertainty and make provisions for them in the event of occurrence; if it is realistic and cost effective.

It is necessary to increase the chance of a project success by identifying the risks associated with the project and taking necessary action against them. Early assessment of sources of risks enhances controllable risk 
factors to be allocated to appropriate party. There are different classifications of risks, depending on the authors and semantics. Risk classification and source are used interchangeably, in a manner connoting the same meaning. Risk sources according to Perry and Hayes (1985) are: physical, environmental, logistics, financial, legal, political; and contractual. Smith (1999) categorized risks into: elemental (project-dependent) and global (non project-dependent). Sources of risk according to Wang et al. (2004) are: internal (comprising client, consultants, contractors and subcontractor, suppliers) and external (comprising economic globalization dynamics, unforeseen circumstances, government/statutory/political control, environmental constraints, health and safety issues, sociocultural issues. Ghosh and Jintanapakanont (2005) classified risk sources into internal and external. Ng and Loosemore (2007) classified PPP project risks in general and project risks. Reconciling the views of the cited authors, risk sources is classified on the basis of the cause of risk, strength of influence of the project stakeholders, and other variables that the project is subject to which are usually outside the control of the project participants.

Risk management can be defined as a systematic controlling of risks that are predicted to be inherent in an investment or project. The need to perform risk management in construction projects is increasing due to growing complexity, size, competition, client/consumer requirements, politic-economic problems, and huge physical complications in such projects. Risk management has become a key element for the completion of projects within time schedule and planned budget, especially in inflation-prone environment (Dawood, 1998). Therefore, risk management in PPP construction projects in Nigeria is necessary because of the high economic inflation situation. A risk management system should establish an appropriate context, set goals and objectives, identify and analyze risk, influence risk decision making; and monitor and review risk responses. There is value management dimension to risk mitigation design. Non-core value-adding variables should be minimized to enhance focusing on significant items because they tend to bring complications. Many projects suffer quality setbacks due to poor value definition and inadequate risk analysis. Value management is primarily entails enhancing value, which often require a comprehensive understanding of the relationship between cost, risk and the associated benefits or profits derivable (Kelly and Pointer-Brown, 1995). Coupling risk management with value management to form an integrated management system must be prioritized during project inception or appraisal phase. Central to risk and value management is the concept of value for money (VFM), which is carried out to determine efficient contract strategies and project solutions. As project become more holistic in nature in relation to sound value management philosophy, pressure is placed upon the assessment made about the quantity of risks allowed in specific contact strategies (Norton and NcElligot, 1995; Smith et al., 2006). Value management allows the project stakeholders (investors, designers, contractors, operators, end-users) to influence project outcome by determining the type of contract strategy most suitable for a particular project by identifying and allocating risks associated with meeting the project objectives (Adebiyi et al., 2016).

\section{FIDIC AND JCT CONDITION OF CONTRACTS}

FIDIC and JCT are generally recognized Conditions of contracts for executing construction works. In Nigeria, FIDIC is commonly used for international civil engineering construction works while JCT is mainly used for building construction works. They state the contractual relationship between the parties to the contract with much emphasis on relationship between the client (usually represented by the Architect or Contract Administrator in JCT and the Engineer in FIDIC) and the Contractor. 


\title{
FIDIC CONDITION OF CONTRACTS
}

'FIDIC' acronym means Federation Internationale Des Ingenieurs-Consiels (in French language and 'International Federation of Consulting Engineers' in English language). FIDIC has over the years produced standard forms of contract for procurement of construction projects internationally and are also widely used in domestic projects with minor modifications. FIDIC's Contract Committee produces standard forms of contract for civil engineering projects which are used globally. The purpose of this standard forms is to define the contractual relationship between the parties and to apportion risks between the contractor and the employer. FIDIC states that their contract condition allocates risks fairly to the party that is best able to bear and control those risks (Fonseka, 2010). This position is corroborated by Hillig (1999) that the Red Book (1987 edition) is regarded by many employers and contractors as the preferred starting point for any new construction contract. The Red Book imposes strict time limits on claims (Sub-clause 20.1) by the contractor, which must be commenced not later than 28 days after the contractor became aware, or should have become aware of the event or circumstance giving rise to claim (Welagedar, 2010). Although this is clearly of benefit to the employer, it also encourages the contractor to be more alert to potential claims and to act upon such claims more promptly, promoting a better claims management process which ultimately benefits both parties (Dodangoda, 2010).

FIDIC forms represent a starting point for the preparation of a construction contract. However, they are routinely amended to reflect the particular characteristics of each project and the requirements of the parties. The forms of contract are drafted for use on a wide range of project types. The choice of form of contract depends on the type of project being contemplated. Distinction between the FIDIC Books is based on the party responsible for the design and the colour of their covers. In summary, these are;

\author{
Straight forward, quick or cheap project (Green Book) \\ Employer Design (Traditional Project) - Red Book \\ Employer Design (Multilateral Development Bank providing finance) - Pink Book \\ Contractor Design (Traditional Project) - Yellow Book \\ EPC/Turnkey project - Silver Book \\ Design, Build, Operate (DBO) Project - Gold Book
}

\section{JOINT CONTRACTS TRIBUNAL (JCT) CONDITIONS OF CONTRACT}

The JCT has developed standard form of construction contracts, guidance notes and other standard forms of documentation for use by the construction industry. JCT contract conditions are basically intended for domestic building projects rather than international projects (IBA, nd). Consequently, where it is used in international projects there is need for reasonable measure of amendments to make it suitable for the project and enhance its delivery benchmarks. It may be described as a 'traditional' contract and has for many years been seen as the standard building contract for use the United Kingdom. This has also led to its common use in former British colonies like Nigeria due to influence of colonialism. According to Keeble (2009), the JCT suite consists of contract families made up of main contracts and subcontracts, together with their documents that can be used across certain contract families. The main JCT forms of contract are: (a) Minor Works Building Contracts, (b) Intermediate Building Contracts, (c) Standard Building Contracts, (d) Design and Build Contract, (e) Construction Management, and (f) Management Building Contract Minor Works Building Contracts and Intermediate Building 
Contracts are commonly used for construction works having small construction cost and short time. Standard Building Contracts is used for large construction projects usually having much construction cost and long construction time. According to JCT (2009), Standard Building Contract with Quantities (SBC/Q) is Appropriate for the following: (i) larger works designed and/or detailed by or on behalf of the Employer, where detailed contract provisions are necessary and the Employer is to provide the Contractor with drawings; and with bills of quantities to define the quantity and quality of the work; and (ii) where an Architect/Contract Administrator and Quantity Surveyor are to administer the conditions. It can also be used where the:

(a) contractor is to design discrete part(s) of the works (Contractor's Designed Portion)

(b) works are to be carried out in sections

(c) private and local authority are employers

Design and Build Contract is used in building construction works whose design and construction responsibilities are carried out by the contractor on behalf of the client. Construction Management conditions of contract is used for building works where the prime contractor executes parts of the construction activities and allocates some work modules contract to subcontractors. However, the prime contractor usually designs the building and in significantly involved in the construction and supervises other subcontractors. Management Building Contract is employed where the prime contractor oversees other module contractors that work packages have been allocated to by the prime contractor. The prime contractor is not directly involved in the construction.

\section{RESEARCH METHODS}

This is an explorative study based on comparative review of payment provisions in FIDIC and JCT conditions of contract as used in Nigeria construction industry. Tabulation of cited provisions was made for enhanced comparative assessment. Furthermore, it involved the following process: (i) critical examination of related payment provisions, (ii) scenario building of problem situations using brainstorming, (iii) assessing the sensitivity of the provisions to contractual conflict, (iv) evaluate the effect on construction cost delivery, and (v) modifications to be made to the provisions to enhance cost delivery. The editions of Conditions used were FIDIC's 'Conditions of Contract for Construction for Building and Engineering Works Designed by the Employer' (Red Book 2006 Edition) and JCT's 'Standard Building Contracts with Quantities (SBC/Q 2009 Edition). The Red Book was selected because it was to a large extent a modified version of the fourth edition of the Conditions of Contract of the UK's Institution of Civil Engineers (ICE) (Ndekugri et al, (2007) and it has broader provisions capable of filling the contractual vacuums in ICE conditions. JCT (SBC/Q 2009 Edition) was used for this study because it is a revised version incorporating wider clauses not covered by previous editions and used for projects where both building and civil engineering works are involved.

In the light of the above, the Red Book and SBC/Q 2009 Edition conditions are used in building and civil engineering works and are used for client-designed projects. They have good comparative characteristics needed to achieve the specific aim of this study. Payment-related clause in FIDIC is 'Contract Price and Payment' (Clause 14) and it is 'Payment' (Clause 4, comprising Contract Sum \& Adjustment, Certificate \& payments, Gross Valuation, Retention, Fluctuation, and Loss \& Expenses) in JCT. The comparison of Payment terms under FIDIC and JCT is limited to: 
Table 1: Comparison of selected payment related provisions in FIDIC and JCT conditions

\begin{tabular}{|c|c|}
\hline FIDIC & JCT \\
\hline $\begin{array}{l}\text { Advance Payment } \\
\text { Sub-Clause } 14.6 \\
\text { (a) Deductions shall commence in the next interim } \\
\text { Payment Certificate following that in which the total } \\
\text { of all certified interim payments (excluding the } \\
\text { advance payment and deductions and repayments of } \\
\text { retention) exceeds } 30 \text { percent ( } 30 \% \text { ) of the Accepted } \\
\text { Contract Amount Less Provisional Sums; } \\
\text { Sub-Clause } 14.6 \\
\text { (b) Deductions shall be made at the amortisation } \\
\text { rate stated in the Contract Data of the amount of } \\
\text { each Interim Payment Certificate (excluding the } \\
\text { advance payment and deductions for its } \\
\text { repayments as well as deductions for retention } \\
\text { money) in the currencies and proportions of the } \\
\text { advance payment until such time as the advance } \\
\text { payment has been repaid; provided that the } \\
\text { advance payment shall be completely repaid } \\
\text { prior to the time when } 90 \text { percent (90\%) of the } \\
\text { Accepted Contract Amount less Provisional } \\
\text { Sums has been certified for payment. }\end{array}$ & $\begin{array}{l}\text { Clause } 4.8 \\
\text { Where the Contract Particulars state that clause } 4.8 \\
\text { applies, the advance payment shall be paid to the } \\
\text { Contractor on the date and reimbursed to the Employer on } \\
\text { the terms stated in the Contract Particulars. Provided that } \\
\text { where the Contract Particulars state that an advance } \\
\text { payment bond is required, payment shall only be made if } \\
\text { the Contractor has provided to the Employer a bond in the } \\
\text { terms set out in Part } 1 \text { of Schedule } 6 \text { from a surety } \\
\text { approved by the Employer. }\end{array}$ \\
\hline $\begin{array}{l}\text { Interim Valuations } \\
\text { Sub-Clause } 14.6 \\
\text { The Contractor shall submit a Statement in six copies } \\
\text { to the Engineer after the end of each month, in a form } \\
\text { approved by the Engineer, showing in detail the } \\
\text { amounts to which the Contractor considers himself } \\
\text { to be entitled, together with supporting documents } \\
\text { which shall include the report on the progress during } \\
\text { this month in accordance with Sub-Clause } 4.21 \\
\text { [Progress Reports]. } \\
\text { Sub clause } 14.7(b) \text {; } \\
\text { The client shall pay to the amount certified in each } \\
\text { Interim Payment Certificate within } 56 \text { days after the } \\
\text { Engineer receives the Statement and supporting } \\
\text { documents; or, at a time when the Bank's loan or credit } \\
\text { (from which part of the payments to the Contractor is } \\
\text { being made) is suspended, the amount shown on any } \\
\text { statement submitted by the Contractor within } 14 \text { days } \\
\text { after such statement is submitted, any discrepancy } \\
\text { being rectified in the next payment to the Contractor. }\end{array}$ & \\
\hline
\end{tabular}




\section{Interim Valuations cont'd}

Sub clause 14.8 (Delayed Payment);

If the Contractor does not receive payment in accordance with Sub-Clause 14.7[Payment], the Contractor shall be entitled to receive financing charges compounded monthly on the amount unpaid during the period of delay. This period shall be deemed to commence on the date for payment specified in Sub-Clause 14.7 [Payment], irrespective (in the case of its subparagraph (b)) of the date on which any Interim Payment Certificate is issued.
Sub clause 4.13(1);

The final date for payment pursuant to an Interim Certificate shall be 14 days from the date of issue of that Interim Certificate.

Sub clause $4.13(6)$;

If the Employer fails properly to pay the amount, or any part of it, due to the Contractor under these Conditions by the final date for its payment, the Employer shall, in addition to the amount not properly paid, pay the Contractor simple interest at the Interest Rate for the period until payment is made. Interest under this clause 4.13 shall be a debt due to the Contractor by the Employer.

Sub clause 4.13(7)

Where there is a failure to issue an Interim Certificate either on time or at all, the Contractor's entitlement to interest shall commence on and be calculated from and including the day immediately following the date that would have been the final ate for payment had that certificate been issued on time.

Sub clause 4.13(1)

The final date for payment pursuant to an Interim Certificate shall be 14 days from the date of issue of that Interim Certificate.

Contractor shall be entitled to receive financing charges compounded monthly on the amount unpaid during the period of delay. This period shall be deemed to commence on the date for payment specified in Sub-Clause 14.7 [Payment], irrespective (in the case of its sub-paragraph (b)) of the date on which any Interim Payment Certificate is issued.

\section{Interim Valuations cont'd}

Sub clause 4.13(6)

If the Employer fails properly to pay the amount, or any part of it, due to the Contractor under these Conditions by the final date for its payment, the Employer shall, in addition to the amount not properly paid, pay the Contractor simple interest at the Interest Rate for the period until payment is made. Interest under this clause 4.13 shall be a debt due to the Contractor by the Employer.

Sub clause $4.13(7)$

Where there is a failure to issue an Interim Certificate either on time or at all, the Contractor's entitlement to interest shall commence on and be calculated from and including the day immediately following the date that would have been the final ate for payment had that certificate been issued on time. 


\section{Retention}

Sub clause 14.9

....Unless otherwise stated in the Particular Conditions, when the Taking-Over Certificate has been issued for the Works and the first half of the Retention Money has been certified for payment by the Engineer, the Contractor shall be entitled to substitute a guarantee, in the form annexed to the Particular Conditions or in another form approved by the Employer and provided by an entity approved by the Employer, for the second half of the Retention Money.

The release of the second half of the Retention Money against a guarantee shall then be in lieu of the release under the second paragraph of this Sub-Clause. The Employer shall return the guarantee to the Contractor within 21 days after receiving a copy of the Performance Certificate.

\section{Final payment}

Sub clause $14.7(\mathrm{c})$

Within 56 days after receiving the Performance Certificate, the Contractor shall submit, to the Engineer, six copies of a draft final statement with supporting documents showing in detail in a form approved by the Engineer:

(a) the value of all work done in accordance with the Contract, and (b) any further sums which the Contractor considers to be due to him under the Contract or otherwise.

Sub clause (14.8)

If the Contractor does not receive payment in accordance with Sub-Clause 14.7[Payment], the Contractor shall be entitled to receive financing charges compounded monthly on the amount unpaid during the period of delay. This period shall be deemed to commence on the date for payment specified in SubClause 14.7 [Payment], irrespective (in the case of its sub-paragraph (b)) of the date on which any Interim Payment Certificate is issued.
Sub clause $4.20(1)$

The Retention Percentage shall be 3 per cent (or such other rate as is stated in the Contract Particulars
Sub clause $4.15(4)$

The final date for payment of the balance shall be 28 days from the date of issue of the Final Certificate.

(i) Advance Payment [Sub-clause 14(2) in FIDIC and Sub-clause 4(8) in JCT]

(ii) Interim Valuations [Sub-clause 14(3), 14(6) in FIDIC and Sub-clause 4(9) - 4(13) in JCT]

(iii) Retention [Sub-clause 14(9) in FIDIC and Sub-clause 4(18) - 4(20) in JCT]

(iv) Final Valuation [Sub-clause 14(2) in FIDIC and Sub-clause 4(8) in JCT]

These four payment terms were selected for appraisal because they are common to both FIDIC and JCT conditions and provide a veritable platform for comparison in the two contract conditions Clauses and Sub-clauses. The provisions relating to Payment in FIDIC and JCT are presented in Table I. 


\section{DISCUSSION}

The discussion covers similarities and dissimilarities in the selected payment provisions.

\section{ADVANCE PAYMENT [FIDIC (14.2) AND JCT (4.8)]}

Both FIDIC and JCT have provisions for advance payment and stipulates that performance bond must be provided prior to the client's paying it. While advance payment is compulsorily required to be provided by the client in FIDIC, it is not absolutely necessary in JCT. Furthermore, there are extensive stipulations in FIDIC in comparison to JCT. For instances;

(1) In Sub clause 14.7(a), the Employer shall pay to the Contractor the first instalment of the advance payment within 42 days after issuing the Letter of Acceptance or within 21 days after receiving the documents in accordance with Sub-Clause 4.2 [Performance Security] and Sub-Clause 14.2 [Advance Payment], whichever is later. The JCT does not stipulate the timeline for advance payment disbursement.

(2) FIDIC further states that the total value of the advance payment, the number and timing of instalment (if more than one), applicable currencies and proportions shall be stated in the Contract Data. It gives elaborate terms for recovering advance payment. It states that unless stated otherwise in the Contract Data, the advance payment shall be repaid through percentage deductions from the interim payments determined by the Engineer in accordance with Sub-Clause 14.6 [Issue of Interim Payment Certificates].

(3) The repayment of advance payment shall commence from the next interim valuation to advance payment valuation certificate and shall be fully repaid prior to the time when ninety percent (90\%) of the Accepted Contract Amount Less Provisional Sums has been certified for payment. These two terms are not negotiable because of the word 'shall'. Therefore, there is greater security for advance payment disbursement and recovery in comparison to JCT which does not contain these provisions. For instance, JCT does not state the latest date the advance payment should be paid to the contractor and recovery of same. The non-inclusion of these terms in JCT could lead to contractual misinterpretation of financial obligations which may lead to disputes. This may further lead to arbitration or litigation thereby reducing the project delivery benchmarks. The Advance Payment (Clause 4.8) in JCT is terse and encourages open-ended interpretation.

(4) FIDIC stipulates that if advance payment has not been repaid by the 28 days prior to the expiry date of the bond, the contractor shall extend the validity of the guarantee until the advance payment has been repaid. JCT does not have these provisions. This implies that the client has less risk in disbursement of advance payment and recovery of same in the event of default by the contractor.

\subsection{INTERIM VALUATIONS [FIDIC (14.3-14.6) AND JCT (4.9 - 4.13)]}

There are some differences in FIDIC and JCT clauses on payments. Examples are:

(1) While FIDIC states that the client is expected to honour Interim Payment Certificate due the contractor within 56 days after the engineer receives the statement, JCT stipulates that the final date for payment pursuant to an Interim Certificate shall be 14 days from the date of issue of that Interim Certificate.

(2) In FIDIC, if the contractor does not receive payment in accordance within the stipulated time of 56 days (Sub Clause 14.7); the contractor shall be entitled to receive financing charges compounded monthly on the amount unpaid during the period of delay. In JCT, the charges incidental to delayed payment shall be computed using simple interest rate. 
(3) JCT empowers the contractor to make claims for delay in issuing of interim certificate. JCT [4.13(7)] states that the contractor shall be entitled to the charges computed at simple interest rate if there is delay in issuing interim certificates in favour of the contractor. FIDIC does not give the contractor the eligibility to make claims for delayed issuance of Interim Certificate. Although both FIDIC and JCT empower the contractor to make claim for delayed payment of Interim Certificate issued in favor of the contractor.

\section{RETENTION [FIDIC (14.9) AND JCT (4.18 - 4.20)]}

Both FIDIC and JCT have virtually the same provisions for Retention. Common observations are:

(1) Contractor's provision of Retention Bond (4.19 in JCT) and (14.9 in FIDIC) in lieu of Retention deduction is recognized by the two contracts. The conditions for paying retention money in FIDIC and JCT are: (i) $50 \%$ of retention money is to be certified and paid to the contractor if a Taking-Over Certificate was issued for a Section or complete work.

(ii) $50 \%$ of retention money is to be certified and paid to the contractor if a after the expiry date of the Defects Notification Period for the Section. This proportion shall be half $(50 \%)$ of the proportion calculated by dividing the estimated contract value of the Section by the estimated final Contract Price.

(2) FIDIC is silent on the exact percentage rate of deduction on Retention money. It also states that is shall be the percentage stated in the Contract Data. However, JCT states the percentage to be $3 \%$ or other stated in the contract particulars. According to JCT [(4.20(1)], 'the Retention Percentage shall be 3per cent (or such other rate as is stated in the Contract Particulars'

\section{FINAL PAYMENT}

This is formally known as Final Payment Certificate in FIDIC and Final Certificate in JCT. The differences in FIDIC [Sub clauses 14.11 (Application for Final Certificate) and 14.13 (Issue of Final Certificate)] and JCT provisions with respect to application and payment of Final Payment include the time the application for the certificate should be made. For instances: (a) In applying for final payment, FIDIC (Sub clause 14.11) says the contractor shall submit to the Engineer six copies of a draft final statement within 56 days after receiving the Performance Certificate. In JCT [Sub Clause 4.15(1)], the Architect/Contract Administrator is to issue the Final Certificate not later than 2 months after the end of the Rectification Period or and date of issue of the Certificate of Making Good. It can be implied that the contractor is contractually likely to receive final certificate (payment) late if FIDIC is used for the contract administration of the project than a contractor that used JCT because would take a FIDIC-based project contractor $112[(2 \times 30)+28]$ days to get paid. (b) In paying for Final Payment, FIDIC [Sub clause 14.7(c)] states that the Employer shall pay the contractor the amount certified within 56 days after the Employer receives the Payment Certificate. In contrast to FIDIC, JCT [Sub clause 4.15(4)] says the final date for payment of the balance shall be 28 days from the date of issue of the Final Certificate. Based on FIDIC provisions on payment of final certificate, it would take the contractor that used FIDIC (56 days) twice the duration it takes a contractor that used JCT (28 days) to get its payment from the client.

Within 28 days after receiving the Final Statement and discharge in accordance with SubClause 14.11 [Application for Final Payment Certificate] and Sub-Clause 14.12 
[Discharge], the Engineer shall deliver, to the Employer and to the Contractor, the Final Payment Certificate which shall state:

(a) the amount which he fairly determines is finally due, and

(b) after giving credit to the Employer for all amounts previously paid by the Employer and for all sums to which the Employer is entitled, the balance (if any) due from the Employer to the Contractor or from the Contractor to the Employer, as the case may be.

If the Contractor has not applied for a Final Payment Certificate in accordance with SubClause 14.11 [Application for Final Payment Certificate] and Sub-Clause 14.12 [Discharge], the Engineer shall request the Contractor to do so. If the Contractor fails to submit an application within a period of 28 days, the Engineer shall issue the Final Payment Certificate for such amount as he fairly determines to be due.

(c) Similar to JCT provision [Sub clause 4.13(7)] that empowers the contractor that make claims for delayed issuance of interim certificates, JCT [Sub clause 4.15(6)] also empowers the contractor to make claims for delayed payment of final certificates and the computation shall be simple interest. Furthermore, it [Sub clause 4.15(8)] states that the interest shall not by any means be taken for waiver of any other payment due to the contractor under the contract. FIDIC also has a similar provision (Sub Cluase14.8) to JCT for claim for delayed payment. The difference is that the computation formula shall be compound interest and shall be paid in the currency agreed in the contract data. If it is in foreign currency, the exchange rate shall be the rate fixed by the central bank of the country where the contract is located.

\section{IMPLICATION ON CONTRACT COST ADMINISTRATION}

Construction contracts are executed in accordance to the memorandum of understanding (MoU) jointly agreed to prior to the contract award and one of the primary components of MOU is conditions of contract. The obligee and obligor of all cost-related commitments are bound by the conditions. Like in all human engagements, risk is inevitable in construction contracts. While the conditions are designed to be safety nets for the contracts, it does not absolutely foreclose 'accidents'. It might catch a bigger fish and freed smaller fish and vice versa depending on the circumstances. These safety nets influence the project's cost administration by determining the liquidity of the client and contracts at certain terms. The implication of these selected payment provisions in FIDIC and JCT on project cost administration is summarized.

\section{ADVANCE PAYMENT}

In contrast to JCT, the FIDIC has wider coverage and rigid terms on advance payment disbursement and amortization. Consequently, FIDIC-based contracts are more secured to risk than JCT-based. It is paradoxical that FIDIC make advance payment computation rigid. While this enhances the contractor cashflow at the project inception, it also makes the amortization rigid in favor of the client than the contractor. The terseness of advance payment terms in JCT exposes it to modifications despite it has relatively low frequency of use than FIDIC (Samer and Kulatuga, nd). 


\section{INTERIM VALUATION}

Interim valuation terms in FIDIC protects the contractor more in payment delay than actual payment. The contractor is expected to make a checklist of works executed and apply for valuation. It stipulates fifty-six (56) days as deadline for making payment and compound interest for computing claims for delayed payment. In contrast, JCT stipulates that payment must be made not later than fourteen (14) days after issue of payment certificate and claim for payment delay to be computed on simple interest term. JCT would enhance the contractor cashflow more than FIDIC because the deadline is four times the FIDIC, i.e. 14 days and 56 days. Also, JCT allows the contractor to make claims for delayed issuance of interim certificate but FIDIC does not give the contractor such right [JCT 4.13(7)] because all application for payments must be made by the contractor to the engineer within certain timeframe. Due to this no-claim window in FIDIC, this could encourage delay in issuing payment certificate and reduces contractor's liquidity.

\section{RETENTION}

FIDIC does not state the term for deducting retention money, JCT put the percentage at three per cent or other stated in the project particular. Retention terms in FIDIC make retention bond in lieu of retention deduction safer for the contractor than in JCT. The requirement for its payment is incidental to application to the engineer and should be applied for within certain time frame. This enhances the contractor's liquidity.

\section{FINAL PAYMENT}

It would take a contractor in FIDIC-based contract a longer time for maturity of final payment than in JCT-based contract. FIDIC requires the contractor to submit six copies of draft final payment within fifty-six (56) days after receiving Performance Certificate and the client is expected to pay the amount certified within fifty-six (56) days of receipt. Consequently, the contractor might not be paid earlier than 112 days. In JCT, the architect/contract administrator is to issue final certificate not less than two months after the end of Rectification Period and the client is expected to honor the Final Payment Certificate within twenty-eight (28) of its issue. In comparison to JCT, it would take a FIDIC-based project contractor $112[(2 \times 30)+28]$ days to get paid. In the light of this, it is safer for a contractor to get retention bond (in lieu of deduction of retention money) to enhance its liquidity.

\section{CONCLUSION}

FIDIC and JCT are recognized conditions of contract for executing construction works in Nigeria. The conditions have varying degree of flexibility of some clauses and this portends construction project administered using FIDIC would have different delivery outcomes due to likelihood of occurrences of some events capable of impeding the project success. Residual risks associated with advance payment, interim certificates, retention and final payment were examined. In contrast to JCT, the FIDIC has wider coverage and rigid terms on advance payment disbursement and amortization. Consequently, FIDIC-based contracts are more secured to risk than JCT-based. The disbursement and amortization of Advance payment in FIDIC are more secured than JCT. Interim valuation in FIDIC allows the contractor to make claims for delayed issuance of interim certificate but FIDIC does not give the contractor such right because all application for payments must be made by the contractor to the engineer. It would take a contractor in FIDIC-based contract a longer time for maturity of final payment than in JCT-based 
contract. It is recommended that a contractor in FIDIC-based contract should get retention bond in lieu of deduction of retention money to enhance its liquidity.

It is suggested that where applicable, some of the clauses should be amended d to suit what is obtainable in the project host country. This is more necessary in Nigeria given the numerous stressors of construction projects in Nigeria. It is nearly impracticable to be strictly legalistic or pedantic in application of the Conditions provisions. For instance, payment delay is prevalent in Nigeria and the delay period is usually more than 56 days stipulated by FIDIC or 28 days recommended by JCT. It is therefore necessary that some dispute-prone clauses be amended to reflect what obtains in Nigeria or the parties to the contracts should be mutually less legalistic to avoid unnecessary face-offs capable to decreasing construction contract success.

\section{REFERENCES}

Adebiyi, J. O., Sanni, G. A \& Kehinde, T. O. (2016). Comparative Assessment between Provisional Sums in Private and Public Client Initiated Project in Nigeria. Civil and Environmental Research, 8(10), 64-68.

Dawood, N. (1998). Estimating project and activity duration: A risk management approach using network analysis. Journal of Management in Engineering, Vol. 14, 67-76.

Dodangoda, L. C. (2010). Extension of Time and Cost Reimbursement claims. SLQS Journal, Journal of Sri Lankan Institute of Quantity Surveyors, Vol. 4, 13-17.

Egan, J. (1998). Rethinking Construction, Department of Environment, Transport and the Regions (DETR): London.

Federation Internationale Des Ingenieurs-Consiels (FIDIC) (2006). Conditions of Contract for Construction for Building and Engineering Works Designed by the Employer (Multilateral Development Banks Edition). Geneva, Switzerland: FIDIC.

Fonseka, H. (2010). Differences in concepts between 1987 Red Book and 1999 Red Book Editions of FIDIC Forms. SLQS Journal, Journal of Sri Lankan Institute of Quantity Surveyors, Vol. 4, 5-12.

Flanagan, R. and Stevens, S. (1995). Risk analysis. In P. S. Brandon (ed.), Quantity surveying techniques- New direction. Oxford: Blackwell Science.

Ghosh, D. \& Jintanapakanont, F. (2005). Modelling global risk factors affecting construction project performance. International Journal of Project Management, 21, 261-269.

Hillig, J. (1999). FIDIC's Red Book 1999 Edition: A study review. Management, Procurement and Law. Vol. 163, Proceedings of the Institution of Civil Engineers (ICE), 129-133.

Hyunchan, C., Masahiko, K. \& Tsuneaki, Y. (1997). BOT project financing in Asian developing countries: Comparative study of structure and risk in BOT power projects. Construkti, Journal of Department of Civil Engineering, University of Tokyo.

International Bar Association (nd). Standard Form Construction Contracts. Accessed from https://www.ibanet.org/Document/Default.aspx?DocumentUid=E2E811DA-E906 on May 18 2017.

Joint Contracts Tribunal Limited (2006). Standard Building Contract with Quantities (SBC/Q). London: Sweet and Maxwell Limited.

Keeble, S. C. (2009). What is best for the contractors? Proceedings of Royal Institution of Chartered Surveyors Rural Research Conference (ROOTS 2009). Cambridge England, 23rd and 24th March, 2009.

Kelly, J. \& Pointer-Brown, R. (1995). Value Management. In P. S. Brandon (ed.), Quantity surveying techniquesNew direction. Oxford: Blackwell Science.

Kwakye, A.A. (1997). Construction Project Administration in practice. London: Longman. 
Love, P., Davis, P., Ellis, J. \& Cheung, S. O. (2010). Dispute causation: identification of pathogenic influences in construction. Engineering, Construction and Architectural Management, 17(4), 404-423.

Murdoch, J. and Hughes, W. (2008). Construction Contract: Law and Management (4th Edn). New York: Routledge.

Ndekugri, I., Smith, N. and Hughes, W. (2007). The engineer under FIDIC's conditions of contract for construction. Construction Management and Economics, 25, 791-799.

$\mathrm{Ng}$, A. \& Loosemore, M. (2007). Risk allocation in the private provision of public of public infrastructure. International Journal of Project Management. 25(1). doi:10.106/j: ijproman.2006.06.005

Norton, B. R. \& McElligot, W. C. (1995). Value management in construction- A Practical Guide. London: Macmillan.

Perry, J. G. \& Hayes, R.W. (1995) Risk and its management in concession projects. Proceedings of Civil Engineers, Part 78, 499-521.

Project Management Institute, PMI (2008). A Guide to the Project Management Body of Knowledge PMBOK. (4th Edn). Pennsylvania: PMI.

Ranatunga, M. (2010). Can time bar clause (20.1 FIDIC 1999) lead to loss of contractors, right? SLQS Journal, Journal of Sri Lankan Institute of Quantity Surveyors, Vol. 4, 23-26.

Samer, S. and Kulatunga, U. (nd). An Overview of Standard Contractual Forms Modifications in the Construction Industry - The Middle East. Accessed from www. usir.salford.ac.uk/37329/ on May $18^{\text {th }}$, 2017.

Sanni, G. A. and Adebiyi, J. O. (2017). Performance Risks Allocation in BOT Infrastructure in Nigeria: a Case Study of Lagos Infrastructure Project. YBL Journal of Built Environment, 5(1), 43-57. doi: 10.1515/jbe-2017-0004

Sanni, G. A. (2012). Evaluation of risks associated with concession contracts in Lagos State. MSc Thesis submitted to the Department of Quantity Surveying, Obafemi Awolowo University, Ile-Ife, Nigeria.

Seeley, I. H. (1996). Building Economics (4th Ed.). Oxford: Blackwell Science.

Smith, N. J., Merna, T. and Jobling, P. (2006) Managing Risk in Construction Projects (2 ${ }^{\text {nd }}$ ed.). Oxford: Blackwell Science.

Smith, N. J. (1999). Managing Risks in Construction Projects. Oxford: Blackwell Science.

Tissera, D. N. (2010). How to deal with an Extension of Time and cost claims. SLQS Journal, Journal of Sri Lankan Institute of Quantity Surveyors, Vol. 4.

Wang, S. Q., Dulaimi, M. F. \& Aguria, M. Y. (2004). Risk management framework for construction projects in developing countries. Construction Management and Economics, 22, 237-252.

Welagedar, S. J. (2010). How to deal with a delay or default by nominated subcontractors in a contract under JCT 1998. SLQS Journal, Journal of Sri Lankan Institute of Quantity Surveyors, Vol. 4. 